\title{
Learning Difficulties of Fourth Graders About The Subject of Fractions in Primary School
}

\author{
Cevdet Epcacan \\ Siirt University, Siirt, Turkey \\ E-mail: epcecan@gmail.com \\ Fatma Ay \\ Siirt University, Siirt, Turkey \\ E-mail: fatma_1863@ hotmail.com
}

\begin{abstract}
This study was carried out to determine the learning difficulties and misconceptions of Grade 4 students on fractions by using the Diagnostic Tree Technique, an alternative assessment and evaluation tool. When studies on the fractions are examined, it has been seen that the data obtained with the Diagnostic Tree Technique are limited. The study group consisted of 8 students in the 4th grade of a primary school in the city center of Batman in 2017-2018 academic year. In order to collect data convergent parallel design, one of the mixed method research designs which both quantitative and qualitative data collection tools utilized were used. The quantitative data were obtained by using the Diagnostic Tree Test and the qualitative data were obtained by semi-structured interview technique. The questions in the diagnostic branched tree test were prepared in accordance with learning outcomes of Ministry of National Education for 4th graders. The reliability of the questions in the test was calculated as 0,79 with the KR20 formula. The frequencies of the answers of the students were calculated by SPSS package program. As a result of the interviews, the results of the students' responses were analyzed and the data obtained from the two data sources were blended in the analyzed findings part. In the light of the obtained data, the misconceptions in the lower learning area of fourth grade students were determined and some suggestions were made to prevent misconceptions.
\end{abstract}

Keywords: Fractions, Misconceptions, Diagnostic Branched Tree, 4th Grade Students

DOI: $10.7176 / J S T R / 5-2-37$

\section{İlkokul 4. Sınıf Öğrencilerinin Kesirler Konusundaki Öğrenme Güçlükleri ${ }^{1}$}

$\ddot{O} z$

$\mathrm{Bu}$ çalışma, 4.sınıf öğrencilerinin kesirler konusundaki öğrenme güçlüklerinive kavram yanılgılarını alternatif ölçme ve değerlendirme araçlarından Tanılayıcı Dallanmış Ağaç tekniği ile tespit etmek için yapılmıştır. Kesirler konusunda yapılan çalışmalara bakıldığında Tanılayıcı Dallanmış Ağaç tekniği ile veri elde edilen çalışmaların sınırlı olduğu görülmektedir. Araştırmanın çalışma grubunu 2017-2018 eğitim-öğretim yılında Batman il merkezindeki bir ilkokulun 4. sınıfında öğrenim gören 8 öğrenci oluşturmaktadır. Verileri toplamak için hem nicel hem de nitel veri toplama araçlarının birlikte kullanıldığ 1 karma yöntem araştırma desenlerinden yakınsayan paralel desen kullanılmıştır. Nicel veriler Tanılayıcı Dallanmış Ağaç testi ile nitel veriler ise yarı yapılandırılmış görüşme tekniği ile elde edilmiştir. Tanılayıcı Dallanmış Ağaç testinde yer alan sorular Milli Eğitim Bakanlığı Matematik Dersi Öğretim Programı 4. Sınıf kesirler konusu kazanımları dikkate alınarak hazırlanmış, testte yer alan soruların güvenirliği KR20

${ }^{1}$ Bu çalışma 6. EğitimProgramlarl ve Öğretimi Kongresinde (10-12 Ekim 2018 Kars) Sözlü Bildiri olarak sunulmuştur. 
formülü ile 0,79 olarak hesaplanmıştır. Öğrencilerin verdikleri cevapların frekansları SPSS paket programı ile hesaplanmıştır. Yapılan görüşmeler sonucu kayıt altına alınan öğrenci cevaplarının çözümlemeleri yapılmış ve analiz edilmiş bulgular kısmında da iki veri kaynağından elde edilen veriler harmanlanarak verilmiştir. Elde edilen veriler ışığında 4.sınıf öğrencilerin kesirler alt öğrenme alanındaki öğrenme güçlükleri ve kavram yanılgıları tespit edilmiş ve kavram yanılgılarının önlenmesi için bazı önerilerde bulunulmuştur.

Anahtar kelimeler: Kesirler, Kavram Yanılgıları, Tanılayıcı Dallanmış Ağaç, 4.Sınıf Öğrencileri

\section{Giriş}

Matematik çoğu öğrenci için öğrenilmesi zor ve sırlarla dolu bir ders olarak görülmektedir (Abdik,Balcı, Demiralp ve Karadağ,2016;Gökkurt,Şahin ve Soylu,2013).PISA matematik okuryazarlığı alanındaki ortalama puanlar incelendiğinde Türkiye'deki öğrencilerin PISA 2015 performansının OECD ortalamalarına göre daha düşük olduğu,1. düzey ve altında (alt yeterlik düzeyi) bulunan öğrenci oranlarının \%51,3 ve 5. düzey ve üstünde (üst yeterlik düzeyi) bulunan öğrenci oranlarının ise \%2,01 olduğu açıklanmıştır. Öğrencilerin matematikte başarılı olabilmeleri için matematiği anlamaları gerekmektedir. Örüntü ve düzen bilimi olarak ifade edilen, düzen ve mantıksal sıralamaya sahip kavram ve işlemler üzerine kurulu bir bilim olan matematiğin, bu düzenini bulup keşfetmek ve sonrasında anlamlandirmak matematik yapmak demektir(Van de Walle, Karp, Bay-Williams, 2012).Matematik formülleri ezberleme veya algoritmaları düşünmeden kullanma değildir. Matematik kuramsal bilgi, işlemsel yetkinlik ve kavramsal anlamanın birlikte kullanımını gerektirir(Van de Walle et al., 2012).Matematikte anlamlı öğrenmeyi amaçlamayan bir öğretim programının başarıya ulaşması beklenemez. Matematiğin her konusunda anlamlı öğrenmelerin olması kavramların doğru anlaşılması çok önemlidir. Matematik konularında programın sarmal yapısından dolayı önceki öğrenmeler sonraki öğrenmeleri etkilemektedir.

Matematik öğretim programının alt öğrenme alanı olan kesirler konusu öğrencilerin anlamakta zorluk çektikleri soyut konuların başında gelmektedir (Haser ve Ubuz,2002;Soylu ve Soylu,2005;Şiap ve Duru,2004).Yapılan çalışmalar öğrencilerin hem ilk hem de orta kademede kesir kavramını tam olarak algılayamadıklarını ve bu konuda kavram yanılgılarına sahip olduklarını göstermiştir(Şiap ve Duru,2004;Ardahan ve Ersoy,2003; Kocaoğlu ve Yenilmez,2010).Kesirler öğrencilerin kavram yanılgılarına sahip oldukları alanlar arasında ilk sıralarda yer almaktadır(Gökkurt et al.,2013). Kesrin ifade ettiği anlamın kavranması, kesirlerin doğal sayılardan farklı sayılar olduklarının fark edilmesi ve kesrin temsil ettiği miktarın öğrenciler tarafından anlaşılmasıyla mümkündür. $\mathrm{Bu}$ da kesrin tüm anlamlarının bilinmesiyle mümkün olmaktadır. Yapılan çalışmalar sonucunda problem durumuna göre a/b şeklinde verilen bir rasyonel sayının farklı anlamlara gelebileceği ortaya çıkmıştır, bu anlamlar aşağıda gösterilmiştir:

1. Parça-Bütün anlamı: Bir bütünün, grubun ya da uzunluğun bir kısmını gösterme anlamına sahiptir,

2. Bölüm Anlamı: Eşit paylaşım gerektiren durumlarda ortaya çıkan bu anlam bölme işlemini ifade etmektedir. Örneğin; 7 cevizin 3 kişi arasında paylaştırılması fikri bölüm anlamını devreye sokmaktadir,

3. Oran Anlamı: Oran, parça-parça ya da parça-bütün ilişkisini ifade etmektedir. Örneğin bir grupta ceket giyenlerin ceket giymeyenlere oranı(parça-parça), ceket giyenlerin tüm gruba oranı(parçabütün) gibi,

4. Ölçme Anlamı: Parça- bütün durumlarında parçaların sayısı üzerinde durulmaktadır, ölçme anlamında kaç tane parçadan ziyade 'ne kadara' odaklanılır,

5. İşlemci(Operatör) Anlamı: Kesirlerle işlem yapma becerilerini ifade etmektedir. Örneğin 12'nin $\frac{3}{4}$ 'ünün ne kadar olduğu bilgisine sahip olmak bu anlamı ifade eder(Van de Walle et al.,2012).

İlkokul Matematik Dersi Öğretim Programı kesirler alt öğrenme alanının içeriği şu şekilde özetlenebilir; 1. sınıfta bütün ve yarım kesirler ile ilgili farkındalık oluşturulmakta, 2. sınıfta bütün ve yarımın çeyrek ile ilişkisi verilmekte,3. sınıfta bölme (gruplandırma, parçalama) işlemine giriş yapılarak parça-bütün ilişsisi vurgulanmakta ve kesire ait terimler tanıtılmaktadır. Ayrıca birim kesir kavramı ele alınarak pay ve payda arasındaki ilişki pekiştirilmektedir. 4. Sınıftaöğrencilerden basit, bileşik ve tam sayılı kesri tanımlamaları ve kullanmaları beklenmekte ve kesirlerde toplama ve çıkarma işlemlerine giriş yapılmaktadır. Paydaları eşit kesirler ile toplama ve çıkarma işlemlerinin yapılması ve uygun problemlerin çözülmesi hedeflenmektedir (MEB,2018). 
Kavram yanılgısı; kavramın bilimsel tanımından farklı algılanması ve bu algılamanın sistemli ve 1 srarcı bir şekilde sürdürülmesi olarak tanımlanmaktadır(Okur ve Gürel, 2016). Öğrencilerin kavram yanılgılarına düşmelerini önlemek için yeni kazandırılacak kavramlar ile mevcut kavramları arasında çelişki yaratacak durumlar ortadan kaldırılmalı, yeni ve eski kavramlar arasında anlamlı bağlar oluşturulmalıdır(Altun ve Çelik, 2018). Bir kavramın öğrenilememesi veya yanlış öğrenilmesi ardışık ve aşamalı bir süreç takip eden matematiksel kavramların sonraki aşamalarını olumsuz etkiler(Önal ve Yorulmaz, 2017). Bu nedenle kavram öğretiminde yanlış öğrenmeler erken tespit edilmeli ve çözüme kavuşturulmalıdır. Kesirler konusunda kavram yanılgılarının oluşmasının nedenleri şu şekilde suralanabilir:

- Ö̈ğrencilerin anlam oluşturmadan çok formülleri ezberlemeye çalışmaları (Şiap ve Duru, 2004; Gökkurt et al., 2013; Orhun, 2007).

- Doğal sayılarla işlem yaparken kullandıkları kuralları kesirlerle işlemlerinde de kullanmaya çalışmaları (Işık ve Kar, 2012; Işık ve Kar, 2014).

- Kesirleri gerçek yaşam durumlarına aktarma performanslarının düşük olması ( Işık ve Kar, 2012).

Kesirler konusunda yapılan çalışmalara baktığımızda öğrencilerin kesir kavramını tam olarak algılayamadıkları (Şiap ve Duru, 2004), kesirlerle ilgili temel kavramların anlamlarına sahip olmadıkları (Orhun, 2007) tespit edilmiştir. Kesirlerde parça-bütün ilişkisini kuramadıkları ve kesir problemlerini anlamakta zorluk çektikleri (Kocaoğlu ve Yenilmez, 2010), kesirleri karşılaştırmada referans noktası stratejilerini etkin bir şekilde kullanamadıkları (Söğüt ve Yazgan, 2018), işlemsel bilgi gerektiren sorularda kavramsal bilgi gerektiren sorulara oranla daha başarılı oldukları (Birgin ve Gürbüz, 2009) görülmüştür.

Öğrenme güçlükleri ve kavram yanılgılarının tespit edilmesinde alternatif ölçme ve değerlendirme yöntemlerinin kullanılması oldukça önemlidir. Öğrencilerin zihinsel yapılarını ortaya çıkaran, öğrenmelerini ölçmeye çalışan yöntemler hem öğretmenler hem de öğrenciler için oldukça önemlidir(Bahar, 2001). Alternatif ölçme ve değerlendirme yöntemlerinden biri olan Tanılayıcı Dallanmış Ağaç tekniği ile öğrencinin bilgi ağındaki yanlış bağlantıları ve kavram yanılgıları ortaya çıkarılmaya çalışılır(Kocaarslan, 2012). Tanılayıcı Dallanmış Ağaç tekniği kesirler konusunda kavram yanılgılarına sahip olan öğrencilerin bu yanılgılarının tespitinde kullanılabilecek bir teknik olarak karşımıza çıkmaktadır.

$\mathrm{Bu}$ araştırmanın amacı Tanılayıcı Dallanmış Ağaç tekniği kullanılarak 4. sınıf öğrencilerinin kesirler konusundaki öğrenme güçlüklerini ve kavram yanılgılarını tespit etmektir. Alternatif ölçme ve değerlendirme yöntemlerinin kullanılması ile geleneksel yöntemlerle tespit edilmesi zor olan ögrenme eksikliklerinin tespit edilmesi hedeflenmektedir. Bu çalışma ile öğrenme güçlüklerinin tespit edilmesinin bu alanda yapılacak çalışmalara rehberlik edeceği düşünülmektedir.

\section{Yöntem}

Bu çalışmada 4.sınıf öğrencilerinin kesirler konusundaki öğrenme güçlüklerini ve kavram yanılgılarını tespit etmek için karma yöntem araştırma modeli kullanılmıştır. Karma yöntem araştırması, araştırma sürecinde hem nitel hem de nicel veri toplama araçlarının kullanıldığı, iki veri türünün aynı anda veya sırasıyla analiz edilerek bir sonuca varılmaya çalışıldığ 1 araştırma olarak tanımlanmıştır(Clark ve Creswell, 2015). Bu karma yöntem çalışmasında yakınsayan paralel karma yöntem deseni kullanılmıştır. Bu desen nicel ve nitel verilerin paralel olarak toplanıp, ayrı ayrı analiz edildiği ve daha sonra birleştirildiği bir desen türüdür(Creswell, 2017). Bu çalışmada nicel verileri toplamak için 10 tane her biri 3 sorudan oluşan Tanılayıcı Dallanmış Ağaç(TDA) diyagramı hazırlanmış ve öğrencilere TDA testi olarak sunulmuştur. Çalışmanın nitel verileri yarı yapılandırılmış görüşme tekniği kullanılarak elde edilmiştir. Yarı yapılandırılmış görüşme tekniğinde araştırmacı sormayı planladığı soruları önceden hazırlar ancak görüşme sırasında yeni sorular sorarak konuyu derinleştirebilir. Hem nicel hem de nitel verilerin toplanma nedeni TDA testinde şans başarısının önüne geçmek ve iki veri kaynağından elde edilen bilgileri karşılaştırarak analiz etmektir.

\section{Çalışma Grubu}

Bu çalışma Batman il merkezindeki bir ilkokulun 4.sınıfında öğrenim gören başarı durumları birbirinden farklı sekiz öğrenci ile 2017-2018 eğitim öğretim y1lı ikinci kanaat döneminde gerçekleştirilmiştir. Araştırmada öğrenciler Ö1,Ö2,Ö3,Ö4,Ö5,Ö6,Ö7 ve Ö8 olarak kodlanmış ve analiz kısmında öğrenci yanıtlarına yer verilmiştir. Öğrencilerin 2017-2018 eğitim ve öğretim yılı birinci kanaat dönemi sonunda başarı durumlarına göre aldıkları belgeler şunlardır: Ö1,Ö2 ve Ö3 takdir belgesi, Ö4,Ö5 ve Ö6 teşekkür 
belgesi almış, Ö6 ve Ö7 belge alamamışlardır. Çalışma, Milli Eğitim Bakanlığı Matematik Dersi Öğretim Programı'ndaki 4.sınıf kesirler konusu kazanımlarına yönelik öğretim sürecini tamamladıktan sonra yapılmıştır. Bu kazanımlar aşağıda sıralanmıştır:

- Basit, bileşik ve tam sayılı kesri tanır ve modellerle gösterir.

- Birim kesirleri karşılaştırır ve sıralar

- Bir çokluğun belirtilen bir basit kesir kadarını belirler.

- Paydaları eşit olan en çok üç kesri karşılaştırır.

- Paydaları eşit kesirlerle toplama ve çıkarma işlemi yapar.

- Kesirlerle toplama ve çıkarma işlemlerini gerektiren problemleri çözer.

\section{Veri Toplama Araçları}

Araştırmada nicel veriler alternatif ölçme ve değerlendirme yöntemlerinden Tanılayıcı Dallanmış Ağaç tekniği, nitel veriler Yarı Yapılandırılmış Görüssme Tekniği ile elde edilmiştir.

Tanılayıcıdallanmış ağaç tekniği:Birbiri ile ilişkili soruların, doğru ve yanlış şeklinde cevaplanmasıyla bir sonraki adıma geçilen bu diyagramda verilen her doğru veya yanlış yanıta bağlı olarak diğer soruya geçilmektedir(Çelikkaya, 2014). Bu teknikle, öğrencilerin kavram yanılgılarına sebep olacak yanlış bağlantıları, yanlış stratejileri ve yanlış öğrenmeleri ortaya çıkarılmaya ve öğretmenlere etkili bir öğrenme ve öğretme süreci düzenlemeleri için rehberlik etmeye çalışılır(Bahar,2001).TDA diyagramı öğrenci seviyeleri dikkate alınarak hazırlanan sekiz veya 16 çıkışlı dallanmış ağaç diyagramına soruların genelden özele bir sırayla yerleştirilmesiyle oluşturulur. Öğrenci sekiz çıkışlı TDA testinde üç, 16 çıkışlı TDA testinde dört soruyu cevaplamak zorundadır. Testin puanlaması iki şekilde yapılabilir:

1. Öğrencinin verdiği doğru yanıtlara bir puan, yanlış yanıtlara da sıfır puan verilerek yapılmasıdır; bu puanlama kavram yanılgılarının tespit edilmesinde kullanılabilir,

2. TDA testinde yer alan her bir bölüme artan değerde veya verilen ifadenin zorluğuna göre puanlar verilerek 100 puan üzerinden bir hesaplama yapılmasıdır; bu puanlama ünite sonu değerlendirmelerde kullanılabilir(Kocaarslan, 2012).

Öğrencilerin kavram yanılgılarını belirlemek için hazırlanan TDA testi ,hazırlık aşamasında 4.sınıf matematik öğretim programı kesirler konusu kazanımları dikkate alınarak hazırlanmıştır.

Kazanımlarla ilgili soru sayıları aşağıdaki tabloda verilmiş̧ir:

Tablo 1. Kesirler konusunda ele alınan kazanımlar ve bu kazanımlara karşıllı gelen soru sayısı.

\begin{tabular}{lc}
\hline Basit, bileşik ve tam sayılı kesri tanır ve modellerle gösterir. & 11 soru \\
\hline Birim kesirleri karşılaştırır ve sıralar. & 1 soru \\
Bir çokluğun belirtilen bir basit kesir kadarını belirler. & 2 soru \\
Paydaları eşit olan en çok üç kesri karşılaştırır. & 12 soru \\
Paydaları eşit kesirlerle toplama ve çıarma işlemi yapar. & 3 soru \\
Kesirlerle toplama ve çıkarma işlemlerini gerektiren problemleri çözer . & 2 soru \\
\hline
\end{tabular}

TDA testinde yer alan sorular Tablo 1'de verilen kazanımlara göre 4.sınıf matematik ders kitabı ve öğretmen kılavuz kitabı incelenerek hazırlanmıştır. Bazı sorular iki farklı kazanımı ölçebilecek niteliktedir.Sorular diyagrama uygun şekilde yerleştirilmiştir. Araştırmacılar tarafından hazırlanan 10 tane 8 çıkışlı TDA testinde öğrenciler toplam 30 soruya cevap vermişlerdir. Puanlama öğrenciler soruyu doğru olarak cevapladılarsa (1) puan, yanlış cevapladılarsa (0) puan verilerek yapılmıştır. Öğrencinin cevapladığı her test için soruyu doğru ve yanlış cevaplama sayıları belirlenerek genel bir değerlendirme yapılmıştır. Veri toplama aracının güvenirliği Kuder- Richardson 20 formülü ile 0,79; Cronbach Alpha katsayısı 0,78bulunmuştur. Testin geçerliliği için matematik ve sınıf öğretmenlerinden görüş alınmıştır. Şekil 1'de hazırlanan TDA testinin bir örneği gösterilmiştir. 


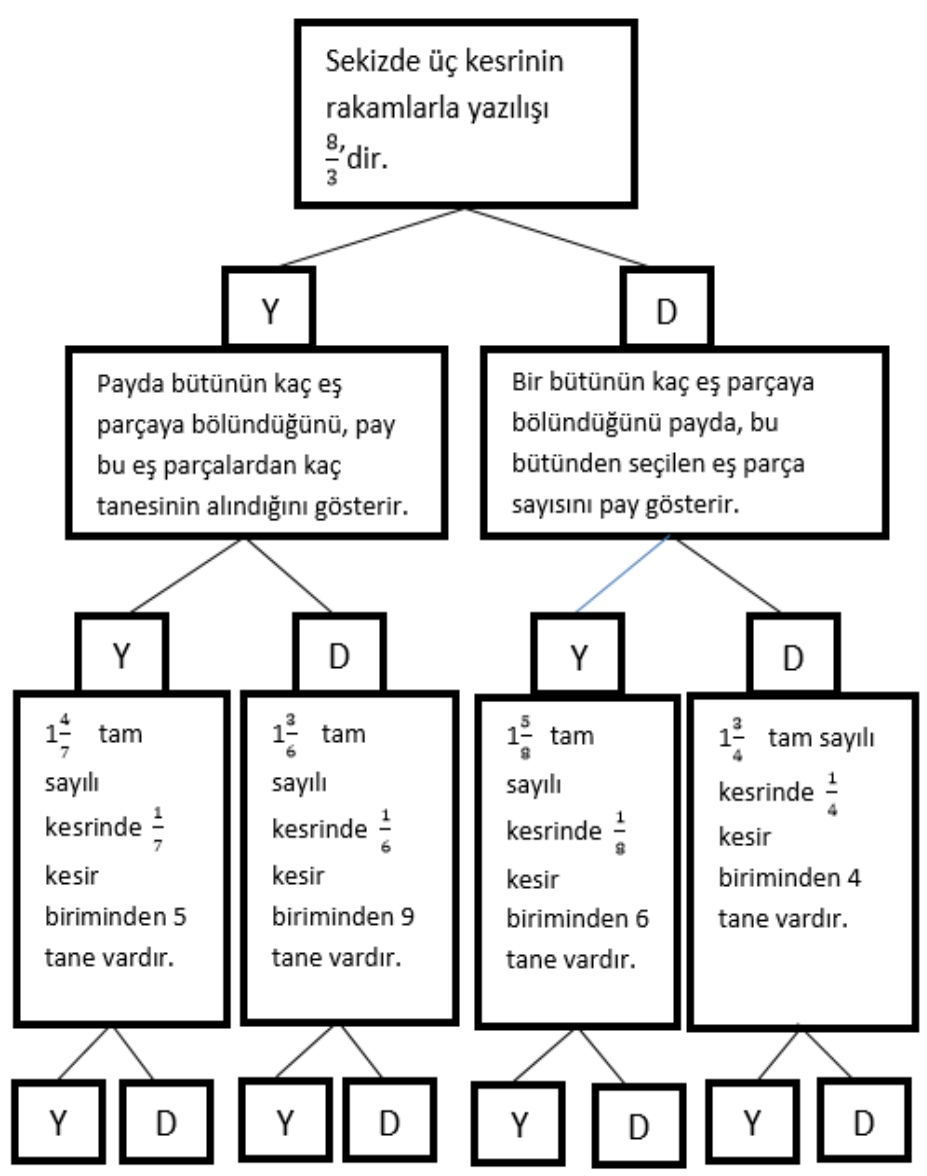

Şekil 1. TDA testi.

Yarı yapılandırılmış görüşme tekniği: Yapılanmış ve yapılanmamış görüşmenin arasında kalan görüşme tekniğidir.( Karasar, 2018). Görüşme sırasında araştırmacı ek sorularla konuyu derinleştirebilir(Karababa ve Candaş, 2009).

Araştırmanın nitel verileri öğrencilerle yapılan görüş̧meler sırasında TDA testine verdikleri cevapları açıklamaları istenerek elde edilmiştir. Öğrencilerle yapılan görüşmeler 40 dakika ile 60 dakika arası sürmüştür. Her testten sonra öğrenciden testteki üç soruyu nasıl çözdügünü anlatması istenmiştir. İşlem yapması gerekiyorsa bunu yapması ve açıklaması için süre verilmiştir. Öğrencinin verdiği cevaplar not edilerek kayıt altına alınmıştır. Ayrıca araştırmacının tespit ettiği öğrenme eksiklikleri de not edilmiştir.

\section{Verilerin Analizi}

Araştırmanın nicel ve nitel verileri birbirine paralel toplanmış, ayrı ayrı analiz edilmiştir. Nicel veriler öğrencilerin TDA testine verdikleri doğru yanıtlarının frekans ve yüzdelikleri alınarak analiz edilmiştir. Öğrencilerin en çok yanlış yaptıkları sorular tespit edilmiş yanlış cevaplama nedenleri belirlenmeye çalışılmıştır. Nitel veriler betimsel analiz tekniğiyle çözümlenmiştir. Betimsel analizde bireylerin görüşlerini yansıtmak amacıyla doğrudan alıntılara yer verilir(Hasan,Şimşek ve Yıldırım, 2016). Sorular öğrencilerin hangi alanlarda kavram yanılgılarına sahip olduklarını belirlemek için kazanımlar dikkate alınarak hazırlanmıştır. Soruyu yanlış cevaplayan öğrencilerin görüşme sırasında verdiği cevaplar çözümlenerek kavram yanılgısının nedenleri ortaya çıkarılmaya çalışılmıştır. Tablo 2.'de TDA testinde yer alan soruların ilgili olduğu kazanımlar gösterilmektedir: 
Tablo 2. Kesirler konusunda ele alınan kazanımlar ve bu kazanımlara karşılık gelen soru numaraları.

\begin{tabular}{|c|c|}
\hline Basit, bileşik ve tam sayılı kesri tanır ve modellerle gösterir. & $\begin{array}{l}\text { 1,2,4,5,6,7,8,9,10,11, } \\
\text { 25.Sorular }\end{array}$ \\
\hline Birim kesirleri karşılaştırır ve sıralar. & 3.soru \\
\hline Paydaları eşit olan en çok üç kesri karşılaştırır. & $\begin{array}{l}\text { 10,11,12,13,14,15,16,17,18,19,20, } \\
21 \text { ve } 23 \text {.sorular }\end{array}$ \\
\hline Bir çokluğun belirtilen bir basit kesir kadarını belirler, & 22. ve 24. Soru \\
\hline Paydaları eşit kesirlerle toplama ve çıkarma işlemi yapar. & 26, 28. ve 29. Sorular \\
\hline $\begin{array}{l}\text { Kesirlerle toplama ve çıkarma işlemi gerektiren problemleri } \\
\text { çözer ve kurar. }\end{array}$ & 27. ve 30. Sorular \\
\hline
\end{tabular}

Bulgular ve Yorumlar

Aşağıdaki tabloda her öğrencinin 30 soruya verdiği toplam doğru ve yanlış cevap sayıları verilmiştir. Öğrenciler Ö1,Ö2,Ö3,Ö4,Ö5,Ö6,Ö7,Ö8 olarak kodlanıp sıralanmıştır, bu siralama öğrencilerin karne notları dikkate alınarak en başarılı olandan en başarısız olanadoğru yapılmıştır.

Tablo 3.Öğrencilerin Verdikleri Cevapların Doğruluk ve Yanlışlık Frekansı

\begin{tabular}{|c|c|c|c|}
\hline Ö1 & 9 yanlış & 21 doğru & \\
\hline Ö2 & & 12 yanlış & 18 doğru \\
\hline Ö3 & & 17 yanlış & 13 doğru \\
\hline Ö4 & & 22 yanlış & 8 doğru \\
\hline Ö5 & & 27 yanlış & 3 doğru \\
\hline Ö6 & & 19 yanlış & 11 doğru \\
\hline Ö7 & & 23 yanlış & 7 doğru \\
\hline Ö8 & & 28 yanlış & 2 doğru \\
\hline
\end{tabular}

1.kazanıma Yönelik Bulgular; 1,4,6. ve 7.Soruların Analizi

Basit, bileşik ve tam sayılı kesri tanır ve modellerle gösterir, kazanımına yönelik aşağıdaki sorular sorulmuştur.

Soru 1: Sekizde üç kesrinin rakamlarla yazılışı $\frac{8}{3}$ ' dir.

Tablo 4.Öğrencilerin 1. ve 4. Sorulara Vermiş Oldukları Cevapların Doğruluk ve Yanlışlık Yüzdesi

\begin{tabular}{lllll}
\hline & \multicolumn{2}{c}{ Doğru } & & \multicolumn{2}{c}{ Yanlıs } \\
\cline { 3 - 5 } & $(\mathbf{f})$ & $(\boldsymbol{\%})$ & $(\mathbf{f})$ & $\mathbf{\%})$ \\
\hline$\underline{\text { 1.soru }}$ & 3 & 37,5 & 5 & 62,5 \\
\hline
\end{tabular}

1.soruda öğrencilerden yazılı olarak verilen ifadeyi kesir sembolüyle göstermeleri istenmiştir.Tablo 4. incelendiğinde öğrencilerin \%37,5'nin soruya verdikleri cevabın doğru olduğu,\%62,5'ininsoruya verdikleri cevabın yanlış olduğu görülmektedir. Aşağıda soruyuyanlış cevaplayan öğrencilerin görüşme sırasındaverdikleri cevaplar gösterilmiştir.

Ö8:: $\frac{8}{3}$ kesrini, $\frac{8}{3}$ (sekiz bölü üç) şeklinde okumuştur. Burada herhangi bir hata yapmamıştır ancak 'sekizde üç' ile 'sekiz bölü üç’ün aynı anlama geldiğini ifade etmiş ve soruyu yanlış cevaplamıştır Ö6: :- $\frac{8}{3}$ kesri için, $\frac{8}{3}$ sekiz bölü üç olduğu için doğrudur, demiştir. Öğrenci bu soruda ondan isteneni anlayamamış soru kökünde geçen sayıları yani sekiz ve üç sayılarını kesirli ifadede $\left(\frac{8}{3}\right)$ görünce doğru kabul etmiştir.

Ö7: Öğrenci $\frac{8}{3}$ kesrini ‘üçte sekiz’ olarak doğru okumuştur ama sekizde üçün( $\left.\frac{3}{8}\right)$, üçte sekiz $\left(\frac{8}{3}\right)$ şeklinde gösterileceğini ifade etmiştir. 
Öğrencilerin verdikleri cevaplar incelendiğinde kesirli ifadeleri okumakla ilgili yanılgılara sahip oldukları görülmektedir. Öğrenciler kesrin bir okunuşuna odaklanmış bu yüzden soruyu yanlış cevaplamışlardır. Bir kesrin 'altıda dört' veya 'dört bölü altı' şeklinde okunması kesrin anlamına bağlıdır. Bu iki anlamın ve okumanın öğrenciye kazandırılması bu konuda yaşanan yanılgıların ortadan kaldırılmasına yardımcı olacaktır.

Soru 4: Șekil 2.

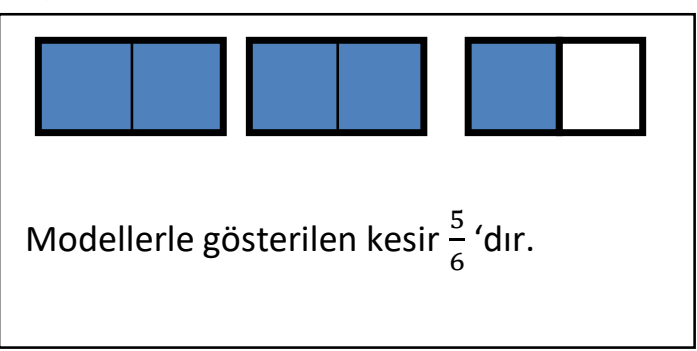

Tablo 5.Öğrencilerin 4. Soruya Vermiş Oldukları Cevapların Doğruluk ve Yanlışlı Yüzdesi

\begin{tabular}{llclll}
\hline & \multicolumn{2}{c}{ Doğru } & & Yanlıs \\
\cline { 2 - 5 } & $(\mathbf{f})$ & $(\%)$ & $(\mathbf{\%})$ & 100 \\
\hline 4.soru & 0 & 0 & 8 & 100 \\
\hline
\end{tabular}

4.soruda öğrencilerin modeli verilen kesre uygun, kesir sayısıyazıp yazamadıkları tespit edilmeye çalışılmıştır. Bu soruyu doğru cevaplamak için modeli verilmiş kesrin iki tamdan oluştuğunu fark etmeleri gerekmektedir. Ancak öğrenciler üç bütün üzerinden işlem yapmak yerine modelleri bir bütün kabul ederek işlem yapmışlar ve payda kısmına eş parça sayısını, pay kısmına da taralı parça sayısını yazarak yanlış cevaplamışlardır. Bu sorunun doğru ve yanlış cevaplanma yüzdelerine bakıldığında bütün öğrencilerin aynı hatayı yaptıkları görülmektedir. Öğrenciler altı parça olduğunu bu parçalardan beş tanesinin işaretlenmiş olduğunu belirterek modele uygun kesir sayısını yanlış yazmışlardır.

Soru 6: Şekil 3.

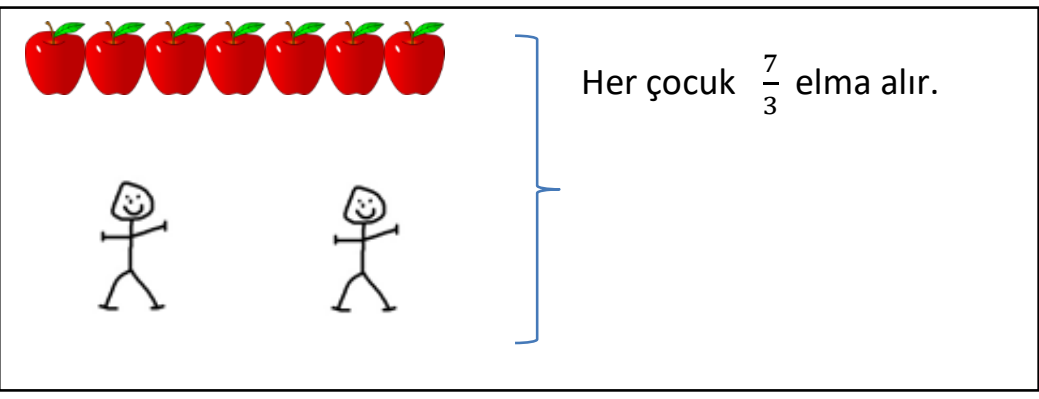

Tablo 6.Öğrencilerin 6. Soruya Vermiș Oldukları Cevapların Doğruluk ve Yanlışlk Yüzdesi

\begin{tabular}{llcccc}
\hline & \multicolumn{2}{c}{ Doğru } & \multicolumn{2}{c}{ Yanlıs } \\
\cline { 2 - 6 } & $(\mathbf{f})$ & $(\%)$ & $(\mathbf{f})$ & $(\%)$ \\
\hline 6.soru & 1 & 12,5 & 7 & 87,5 \\
\hline
\end{tabular}

Altıncı soru ile öğrencilerin kesrin bölme anlamının farkında olup olmadıkları tespit edilmeye çalışılmıştır. Tablo 6.'da bu soruyu doğru cevaplama yüzdesinin(\%12,5) düşük olması dikkat çekmektedir. Bu soruda elma sayısının (7), çocuk sayısının (2) olması öğrencilerin eşit paylaşım yapılamaz şeklinde bir yargıya varmalarına neden olmuş ve soruyu yanlış cevaplamışlardır. Aşağıda bazı öğrencilerin bu soruya verdikleri cevaplar verilmiştir(TDA testinde bu soruyla aynı kazanımı ölçen bu sorudan farklı 3 soru daha vardır. Aşağıdaki öğrenci cevaplarında elma ve çocuk sayılarının farklı olmasının nedeni bu durumdur.) : 
Ö1: Soru kökünde 5 elma 3 çocuğa paylaştırılacaktır. Öğrenci önce her çocuğa elma düşmeyeceğini söylemiş daha sonra herkese 1 elma düşeceğini söylemiştir. Geriye kalan elmalar için fikir belirtmemiştir. Ö3: Soru kökünde 5 elma 3 çocuğa paylaştırılacaktır. Öğrenci, her çocuk için yeterli elma olmadığını söylemiştir.

Ö4: Soru kökünde 7 elma 3 çocuğa paylaştırılacaktır. Öğrenci, elmaları üçer üçer dağıtmış bu durumda 2 elmanın eksik olduğunu belirtmiştir.

Ö5: Soru kökünde 5 elma 3 çocuğa paylaştırılacaktır. Öğrenci, elmaları 221 şeklinde çocuklara dağıtmıştır. Bir çocuğun 1 elma aldığını belirtmiştir.

Ö6: Soru kökünde 5 elma 3 çocuğa paylaştırılacaktır. Öğrenci, 5 elmanın 3 çocuğa paylaştırılamayacağını, elma sayısının 6 veya 9 olması gerektiğini söylemiştir.

Ö8: Soru kökünde 7 elma 3 çocuğa paylaştırılacaktır. Öğrenci, elmaları 2-2-3 şeklinde çocuklara dağıtmıştır.

Öğrencilerin verdikleri cevaplar incelendiğinde elmaları çocuklara eşit bir şekilde paylaştırmaya çalıştıkları görülmektedir. Bu eşit paylaşımı elmaları teker teker dağıtarak yaptıkları görülmektedir. Öğrenciler eşit paylaşım olmadığında farklı bir yol denemek yerine durumu kabullenmeyi tercih etmişlerdir. Sadece bir öğrencinin bölme yapılabilir demesi öğrencilerin kesirli sayılar ile bölme arasında ilişki kuramadıklarını göstermektedir. Toluk (2002), yaptığı çalışmada öğrencilerin kesirli sayılardan bölmeye geçerken zorlandıklarını tespit etmiştir.

Soru 7. Şekil 4.

0

A1

A noktasına karşılık gelen kesir $\frac{4}{6}$ tür.

Tablo 7.Öğrencilerin 7. Soruya Vermiş Oldukları Cevapların Doğruluk ve Yanlışlık Yüzdesi

\begin{tabular}{llllll}
\hline & \multicolumn{2}{c}{ Doğru } & & \multicolumn{2}{c}{ Yanlıs } \\
\cline { 2 - 5 } & $(\mathbf{f})$ & $(\%)$ & $(\mathbf{f})$ & $(\%)$ \\
\hline$\underline{7 . s o r u}$ & 3 & 37,5 & 5 & 62,5 \\
\hline
\end{tabular}

7. soruda öğrencilerin payı ve paydası en çok iki basamaklı sayı olan kesirleri sayı doğrusunda gösterir, kazanımını edinip edinemedikleri tespit edilmeye çalışılmıştır. Tablo 7'de görüldüğü gibi 7.soruyu öğrencilerin \%37,5'i soruyu doğru çözmüş, \%73,5'i soruyu yanlış çözmüştür. Yanlış cevaplayan bazı öğrencilerin cevapları aşağıda verilmiştir:

Ö3: 0'dan başlayarak 1'e kadar olan noktaları saydı. Paya 4, paydaya 6 yazarak kesri oluşturdu. Ö4: Bütüne dikkat etmeden sayı doğrusu üzerindeki bütün noktaları sayarak işlem yaptı. Ö5:Dörtte bir, dörtte iki, dörtte üç şeklinde her noktayı isimlendirerek ilerledi. Ö6: Noktaları sayarak işlem yaptı. Paydaya 6, paya 4 nokta yazılacağını söyleyerek soruyu cevapladı.

Sayı doğrusu modelinde her iki nokta arası bir bütün olarak kabul edilmektedir. Öğrencilerin verdikleri cevaplar incelendiğinde bir bütünün iki nokta arasında olması gerektiğine dikkat etmeden işlem yaptıkları görülmektedir. Öğrencilerin iki nokta arasındaki eş parçaları saymak yerine noktaları saydıkları görülmektedir. Noktaları saymaya 0'dan başlayıp 1'e kadar giden, 0 ile 1 arasındaki noktaları sayan, 0'dan sonraki noktadan başlayıp 1'e kadar sayan öğrenciler olmuştur. Pesen (2008), araştırmasında öğrencilerin aralıklar yerine noktaları saydıklarını belirtmiştir. Bu öğrencilerin sayı doğrusu üzerinde parça bütün ilişkisini kavrayamadıkları ve payı ve paydayı belirlerken noktaları sayarak işlem yaptıkları tespit edilmiştir.

\section{Kazanıma Yönelik Bulgular; 3.Sorunun Analizi}

Birim kesirleri karşılaştırır ve sıralar, kazanımına yönelik aşağıdaki soru sorulmuştur.

Soru $3: 1 \frac{3}{4} \quad$ tam sayılı kesrinde $\frac{1}{4}$ kesir biriminden 4 tane vardır. 
Tablo 8.Öğrencilerin 3. Soruya Vermiş Oldukları Cevapların Doğruluk ve Yanlışlık Yüzdesi

\begin{tabular}{|c|c|c|c|c|}
\hline & \multicolumn{2}{|c|}{ Doğru } & \multicolumn{2}{|c|}{ Yanlus } \\
\hline & (f) & $(\%)$ & (f) & $(\%)$ \\
\hline 3.soru & 0 & 0 & 8 & 100 \\
\hline
\end{tabular}

3.soruda öğrencilerin kesrin birimini gösterip gösteremedikleri tespit edilmeye çalışılmıştır. 3. Sorunun doğru cevaplanma yüzdesine bakıldığında bu yüzdenin çok düşük olduğu görülmektedir. Öğrenciler tam sayılı kesrin kaç tane birim kesirden oluştuğunu ifade edememişlerdir. Soruyu anlamakta güçlük çekmişler, kesrin birimi nedir deyince cevap verememişlerdir. Bu sonuçlara bakarak öğrencilerin kesrin birimini gösteremedikleri söylenebilir.

\section{Kazanıma Yönelik Bulgular; 10,12,16. ve 18.Soruların Analizi}

Paydaları eşit olan en çok üç kesri karşılaştırır, kazanımına yönelik aşağıdaki soru sorulmuştur.

Soru 10: Ali ve Mehmet bir pizzayı 4 eş parçaya ayırmıştır. Ali bu eş parçalardan 3 tanesini, Mehmet 1 tanesini yemiştir. Bu durumda Mehmet daha çok pizza yemiştir.

Tablo 9.Öğrencilerin 10. Soruya Vermiş Oldukları Cevapların Doğruluk veYanlışlık Yüzdesi

\begin{tabular}{llllll}
\hline & \multicolumn{3}{c}{ Doğru } & & \multicolumn{2}{c}{ Yanlıs } \\
\cline { 2 - 5 } & (f) & $(\%)$ & (f) & (\%) \\
\hline$\underline{\text { 10.soru }}$ & 4 & 50 & 4 & 50 \\
\hline
\end{tabular}

Bu soruda öğrencilerden sözel olarak verilen soruyu anlamaları ve karşılaştırma becerilerini kullanmaları beklenmektedir. Tablo 9. incelendiğinde öğrencilerin \% 50'sinin soruyu doğru cevapladığı, \%50'sinin de yanlış cevapladığı görülmektedir. Görüşme sırasında elde edilen öğrenci cevapları analiz edildiğinde öğrencilerin parçaları karşılaştırdıkları ve buna göre işlem yaptıkları görülmüştür. Soruyu yanlış cevaplayan 2 öğrencinin soruyu anlayamadıkları için yanlış yaptıkları tespit edilmiştir. Bu soruyu çözerken öğrencilerin pizza dilimlerinin eşit olmasına dikkat edip etmedikleri de tespit edilmeye çalışılmıştır. Bunu tespit etmek için onlara şu sorular sorulmuştur: 'Pizza dilimlerinin eşit olduğunu nasıl anlıyoruz? Pizza dilimleri farklı boyutta olsaydı bu durumda en çok yiyen kim olurdu?' vb. Verilen cevaplar incelendiğinde 8 öğrenciden sadece birinin soruda geçen 'eş parçalar' ifadesine dikkat ettiği görülmüştür. Öğrencilerin parçaların eşit büyüklükte olmalarına dikkat etmedikleri, 'eş parçalar' ifadesiyle ne anlatılmak istendiğinin farkında olmadıkları söylenebilir.

Soru 12. $\frac{19}{21}<\frac{18}{21}$ Soru 18. $\frac{7}{4}>\frac{7}{9}$

Tablo 10.Öğrencilerin 12. ve 18. Soruya Vermiş Oldukları Cevapların Doğruluk ve Yanlışlık Yüzdesi

\begin{tabular}{lllll}
\hline & \multicolumn{2}{c}{ Doğru } & & \multicolumn{2}{c}{ Yanlıs } & \\
\cline { 2 - 5 } & (f) & $(\%)$ & $(\mathbf{f})$ & 25 \\
\hline$\underline{\text { 12.soru }}$ & 6 & 75 & 2 & 75 \\
\hline 18.soru & 2 & 25 & 6 & 75 \\
\hline
\end{tabular}

Verilen iki basit kesri karşılaştırmayı gerektiren bu soruda öğrencilerin soruyu doğru cevaplama yüzdeleri yüksek çıkmıştır(\%75). Bu soruyu çözerken öğrencilerin paylara bakarak sonuca gittikleri tespit edilmiştir. Paydaların eşit olduğuna sadece iki öğrenci dikkat etmiş diğer öğrenciler paydaya dikkat etmeden işlem yapmışlardır. Bileşik kesirlerin karşılaştırılması ile ilgili olan 18.soruda öğrencilerin soruyu doğru cevaplama yüzdelerinin düştüğü görülmektedir. 18 .soruya öğrencilerin sadece $\% 25$ 'i doğru cevap vermiştir. 18.soruda öğrenciler payların aynı olduğunu belirtip paydası büyük olan kesre büyük demişlerdir. Öğrenciler kesrin tamamı hakkında düşünmeden, payı ve paydayı iki ayrı sayı olarak görmekte ve sayıların sayı değerlerine göre işlem yapmaktadırlar. 
Soru 16. $\quad \frac{9}{9}>1$

Tablo 11.Öğrencilerin 16. Soruya Vermiş Oldukları Cevapların Doğruluk ve Yanlışlık Yüzdesi

\begin{tabular}{|c|c|c|c|c|}
\hline & \multicolumn{2}{|c|}{ Doğru } & \multicolumn{2}{|c|}{ Yanlis } \\
\hline & (f) & $(\%)$ & $(\%)$ & \\
\hline 16.soru & 1 & 12,5 & 7 & 87,5 \\
\hline
\end{tabular}

16. soruda öğrencilerin bir bütünün kesir sayısı olarak karşılığını bilip bilmedikleri tespit edilmeye çalışılmıştır. $\mathrm{Bu}$ soruyu öğrencilerin \% 87,5'i yanlış cevaplamıştır. $\mathrm{Bu}$ oran oldukça yüksektir. Öğrencilerin, $\frac{9}{9}$ kesrinin bir bütüne eşit olduğu bilgisine sahip olmadıklarını söyleyebiliriz. Öğrenciler karşılaştırma yaparken $\frac{\mathbf{9}}{\mathbf{9}}$ ü bir kesir olarak değil payı ve paydası ile ayrı 2 sayı olarak görmüşler ve buna göre karşılaştırma yapmışlardır. Görüşme sırasında elde edilen öğrenci cevaplarından bazıları aşağıda verilmiştir:

Ö6: Dokuz bölü dokuz daha büyüktür. 2 tane 9 vardır.

Ö5: 1 tam kesirlerden daha büyüktür.

Ö2: Dokuzun içinde dokuz bir defa vardır. Dokuz bölü dokuz büyüktür.

Ö8: Dokuz bölü dokuz bire eşittir. Hem bire eşit hem de birden büyüktür.

Ö1: Dokuz bölü dokuz büyüktür.1 tam küçüktür.

Öğrencilerin verdikleri cevaplar incelendiğinde Ö6'nın sayı değerlerine göre işlem yaptığı, Ö5'in basit kesirler için geçerli olan kuralı genellediği görülmektedir. Ö8'in sahip olduğu bilgileri zihninde yapılandıramadığı için yanılgıya düştüğü söylenebilir.

\section{Kazanıma Yönelik Bulgular; 24. Sorunun Analizi}

Bir çokluğun belirtilen bir basit kesir kadarını belirler, kazanımına yönelik aşağıdaki soru sorulmuştur.

Soru24: $15^{\prime}$ 'in $\frac{4}{5} 12^{\prime}$ dir.

Tablo 12. Öğrencilerin 24.Soruya Vermiş Oldukları Cevapların Doğruluk ve Yanlışlık Yüzdesi

\begin{tabular}{llllll}
\hline & \multicolumn{3}{c}{ Doğru } & & \multicolumn{2}{c}{ Yanlıs } & $(\boldsymbol{\%})$ \\
\cline { 2 - 6 } & $(\mathbf{f})$ & $(\boldsymbol{\%})$ & $(\mathbf{f})$ & 63,5 \\
\hline$\underline{\mathbf{2 4 . s o r u}}$ & 3 & 37,5 & 5 & \\
\hline
\end{tabular}

24. soruda öğrencilerin bir çokluğun belirtilen bir basit kesir kadarını belirler kazanımını edinip edinemedikleri tespit edilmeye çalışılmıştır. Tablo 12.'ye bakıldığında öğrencilerin \%63,5'inin soruyu yanlış cevapladığ 1 görülmektedir. Görüşme sırasında elde edilen veriler analiz edildiğinde doğru cevap veren öğrencilerin düşünmeden işlem yaptıkları tespit edilmiştir. Öğrenciler öğrendikleri kuralları uygulamışlar, 15'i 5'e bölmeli çıkan sonuçla 4'ü çarpmalıyız diyerek soruyu nasıl çözdüklerini anlatmışlardır. Soruyu çözerken hiçbir öğrencinin şekil çizmemesi dikkat çeken başka bir noktadır. Basit bir eş parçalara ayırma sorusunu, kesir öğretiminde ilk adımından itibaren kullanılan modellerle ilişkilendiremedikleri görülmüştür.

\section{Kazanıma Yönelik Bulgular;26. ve 28.Sorunun Analizi}

Paydaları eşit kesirlerle toplama ve çıkarma işlemi yapar, kazanımına yönelik aşağıdaki soru sorulmuştur.

Soru 26: $\frac{6}{9}+\frac{11}{9}=\frac{17}{18}$ 
Tablo 13. Öğrencilerin 26.Soruya Vermiş Oldukları Cevapların Doğruluk ve Yanlışlık Yüzdesi

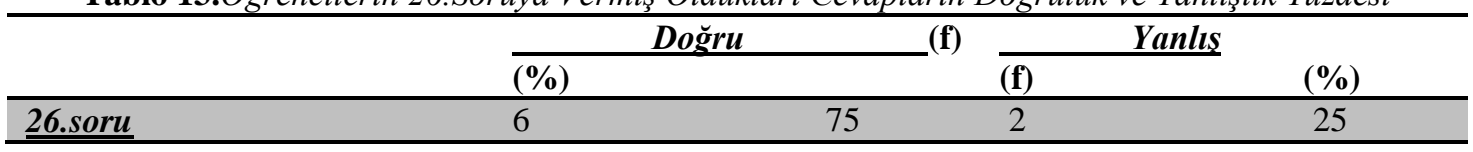

26.soruda öğrencilerin paydaları eşit kesirlerle toplama işlemi yapar kazanımını edinip edinemedikleri tespit edilmeye çalışılmıştır. Öğrencilerin kesirlerde toplama işlemi yapma becerilerinin yüksek olduğu görülmektedir. Yanlış cevaplayan öğrencilerin pay ve paydaları ayrı ayrı toplayarak yanılgıya düştükleri tespit edilmiştir.

Soru 28: $\frac{9}{19}-\frac{8}{9}=\frac{1}{10}$

Tablo 14.Öğrencilerin 28.Soruya Vermiș Olduklarl Cevapların Doğruluk ve Yanlıșlık Yüzdesi

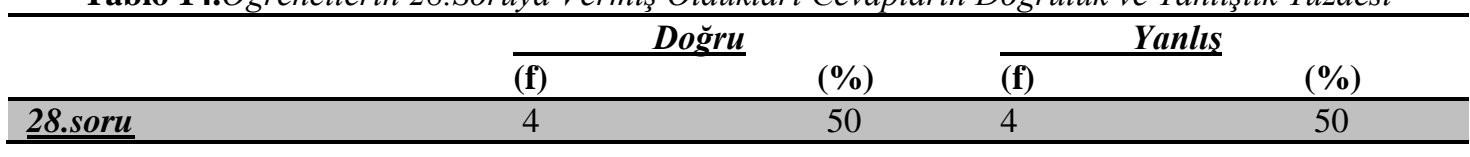

28.soruda öğrencilerin paydaları eşit kesirlerle çıkarma işlemi yaparkazanımını edinip edinemedikleri tespit edilmeye çalışılmıştır. Bu soruyu öğrencilerin \%50'si doğru, \%50'si yanlış cevaplamıştır. Yanlış cevaplayan öğrencilerden elde edilen verilere bakıldığında payları ve paydaları ayrı ayrı çıkarttıkları görülmektedir. Ö6'nın soruyu yanlış cevaplamasının nedeni paydaların farklı olmasından dolayı yaşadığ belirsizliktir. Görüşme sırasında verdiği cevapta eğer paydalar aynı olsaydı paydaları çıkartmazdık demiştir. Paydalar farklı olduğu için payları ve paydaları kendi aralarında çıkarmış ve sonucu bulmuştur. $\mathrm{Bu}$ cevabı onun eşit paydalı kesirler için geçerli olan bu kuralın paydalar eşit olmadığında değiştirilebileceği düşüncesinde olduğunu göstermektedir.Paydalar eşit değilse çıkarma işlemi yapılamayacağı kazanımını edinemediği söylenebilir.

\section{Kazanıma Yönelik Bulgular;27. Sorunun Analizi}

Kesirlerle toplama ve çıkarma işlemlerini gerektiren problemleri çözer,kazanımına yönelik aşağıdaki soru sorulmuştur.

Soru 27: 18 cevizin $\frac{1}{3}$,ini Ali, $\frac{2}{3}$, sini Ömer almıştır. Bu durumda geriye 12 ceviz kalmıştır.

Tablo 15: Öğrencilerin 27.Soruya Vermiş Oldukları Cevapların Doğruluk ve Yanlışlık Yüzdesi

\begin{tabular}{|c|c|c|c|c|}
\hline & \multicolumn{2}{|c|}{ Dŏ̆ru } & \multicolumn{2}{|c|}{ Yanlis } \\
\hline & $\overline{(f)}$ & $(\%)$ & $\overline{\text { (f) }}$ & $(\%)$ \\
\hline 27.soru & 1 & 12,5 & 7 & 87,5 \\
\hline
\end{tabular}

27. soruda öğrencilerin kesirlerle işlem gerektiren problemleri çözer kazanımını edinip edinemedikleri tespit edilmeye çalışılmıştır. Bu sorunun doğru cevaplanma yüzdesi $(\% 12,5)$ oldukça düşüktür. Öğrencilerin büyük çoğunluğu sorunun çözümü hakkında fikir üretememişlerdir. Öğrencilerin problem durumunu anlayamadıkları ve soruyu çözmek için bir strateji üretemedikleri tespit edilmiştir.

\section{Sonuç ve Öneriler}

$\mathrm{Bu}$ araştırmanın bulguları değerlendirildiğinde öğrencilerin belirlenen kazanımlara ulaşmada başarılı olamadıklarıgörülmektedir. Öğrencilerin kesrin ifade ettiği anlamı anlamakta güçlük çektikleri tespit edilmiştir. Sözel olarak verilen ifadeyi kesir sembolüyle göstermede öğrencilerin \%67,5'i başarısız olmuştur. Modellerle gösterilen tam sayılı kesri sembolle göstermede başarısız oldukları, modeldeki bütünleri fark edemedikleri modelle verilen $2 \frac{1}{2}$ kesrini $\frac{5}{6}$ şeklinde ifade ettikleri görülmüştür.Pesen (2008), çalışmasındaöğrencilerin kesir sayısının kaç birimden oluştuğunu belirlemede düşük performans gösterdiklerini belirtmiştir.Uslu(2006)'da yaptığ 1 çalışmada öğrencilerin şekil veya şema ile verilen kesrin 
birimini yazmada eksik bilgiye sahip olduklarını tespit etmiştir. Ersoy ve Ardahan (2003), birim kesir kavramının öğrenciler tarafından tam olarak anlaşılamadığını ifade etmiştir.

Öğrencilerin kesir ve bölme işlemi arasındaki ilişkiyi fark edemedikleri görülmüştür.Öğrenciler eşit paylaşım yapmalarının istendiği soruda soru kökünde kesirli ifadenin olmasını anlamlı bulmamışlar, bölme işlemi ile kesirler arasında ilişki kuramamışlardır. Toluk (2002), çalışmasında öğrencilerin kesir ve bölme kavramlarını kendi kendilerine ilişkilendiremediklerini tespit etmiştir.

Öğrencilerin basit kesirleri karşılaştırmada, bileşik kesirleri karşılaştırmaya göre daha başarılı oldukları görülmüştür. Bu durumun nedeni öğrencilerin kesir ifadesindeki sayıların sayı değerine göre karşılaştırma yapma eğilimleri içinde bulunmaları sonucunda basit kesirlerde bu mantığın sonuçlarının doğru çıkması ama bileşik kesirlerde bunun tam tersinin olması söylenebilir. Öğrenciler $\frac{4}{9}$ ile $\frac{5}{9}$ karşılaştırırken sayı değerine bakarak 54 'ten büyüktür bunun için $\frac{5}{9}$ daha büyüktür demektedirler, bu durumu bileşik kesirlere uyguladıklarında $\frac{9}{5}, \frac{9}{4}$ 'ten büyüktür demekte ve yanılgıya düşmektedirler.

Önal ve Yorulmaz (2017),öğrencilerin kesirleri sıralamada doğal sayıları sıralama alışkanlıklarını kullandıklarını belirtmiştir. Kesirleri karşılaştırmada payın ve paydanın ifade ettiği miktarı, çokluğu veya uzunluğu kavrayamayan öğrenciler doğru stratejiler geliştirememektedirler. Öğrencilerin kesirleri karşılaştırmada basit kesirlerin 1'den küçük olduğu bilgisini bileşik kesirler için de uygulama yanılgısında oldukları görülmüştür.

Öğrencilerin kesirlerde toplama ve çıkarma işlemi yaparken paydaların eşit olma kuralına toplama işleminde daha çok dikkat ettikleri görülmüştür. Öğrencilerin payda eşitliğini dikkate almadan payları toplayıp ya da çıkardıkları daha sonra payda için işleme geçtikleri görülmüştür. Eşit paydalı kesirlerle yaptıkları işlem kurallarını paydaları farklı kesirlere de uyguladıkları görülmüştür.Birgün ve Gürbüz (2009), çalışmalarında öğrencilerin kesrin paydasının eşit olmasına dikkat etmeden işlem yaptıklarını, parçaların eşitliğini gözardı ettiklerini, eş parçalarmış gibi düşünüp işlem yaptıklarını belirtmişlerdir. Orhun(2007), çalışmasında öğrenci hatalarının odak noktasının payda eşitliğine dikkat edilmeden işlem yapılması olduğunu gözlemlemiştir.

Öğrencilerden sadece biri $\frac{9}{9}$ kesrinin 1'e eşit olduğunu söylemiş diğer öğrenciler sayı değerlerini karşılaştırma yanılgısına düşmüşlerdir. Bir bütünü, kesir ifadesi olarak belirtemedikleri görülmüştür. $\mathrm{Bu}$ durumun nedeni olarak öğrencilerin kesir ifadesindeki pay ve paydanın anlamını kavrayamamış olmaları gösterilebilir.Haser ve Ubuz (2002), öğrencilerin birden fazla bütün içeren sorularda tutarsız cevaplar verdiğini tespit etmiştir.

Kesir öğretiminde anlamlı öğrenmelerin sağlanması kavram yanılgılarının önlenmesinde çok önemlidir. Kesrin ifade ettiği miktarın öğrenci tarafından ifade edilmesi sağlanmalı, somut materyaller kullanılarak kesirler tanıtılmalıdır. Kesrin farklı anlamları üzerinde durulmalı bu anlamlar öğrenciye hissettirilmelidir. Kesirleri karşılaştırmada farklı stratejiler kullanılarak karşılaştırma yapma becerileri geliştirilmelidir.

\section{Kaynakça}

Abdik,E.,Balc1,M.,Demiralp,A. \& Karadağ,S.(2016). Günümüzde matematik eğitimi.InG.Oğuz.(Ed), Illkokul matematik ögretmen kılavuz kitabı (ss 15-25).Ankara: Yakın Çağ Yayınları.

Altun,H.\& Çelik,A. (2018). Kesir ve rasyonel sayılar konusu ile ilgili öğrencilerin ilgi ve düşünceleri.International Journal of New Trends in Arts, Sports \&Science Education, 7(1).

Ardahan,H. \&Ersoy,Y.(2003).ilköğretim okullarında kesirlerin öğretimi-2:tanıya yönelik etkinlikler düzenleme. 11 Ağustos 2018 tarihinde,http://www.matder.org.tr adresinden alınmıştır.

Bahar, M. (2001). Çoktan seçmeli testlere eleştirel bir yaklaşım ve alternatif metodlar. Kuram ve Uygulamada Eğitim Bilimleri Dergisi, 1(1), 23-38.

Birgin,O.\& Gürbüz, R. (2009). İlköğretim II. kademe öğrencilerinin rasyonel sayılar konusundaki işlemsel ve kavramsal bilgi düzeylerinin incelenmesi. Eğitim Fakültesi Dergisi, 22(2), 529-550. 
Gökkurt,B., Şahin,Ö.\& Soylu,Y.(2013).Kitap incelemesi. Ilköğretim Online, 12(3), 1-6.

Clark,V.L.P.\& Creswell,J.W.(2015). Karma yöntem araştırmalarının doğası. InD. Yüksel \& B. D. Selçuk. (Eds), Karma yöntem araştırmaları (ss. 2-22). Ankara: Anı Yayıncılık.

Creswell, J. (2017). Araştırma deseni. Ankara: Eğiten Kitap Yayınları.

Çelikkaya, T. (2014). Eğitimde ölçme ve değerlendirme. Ankara: Nobel Akademik Yayıncılık.

Şimşek,H \&Yıldırım, A. (2016). Nitel araştırma yöntemleri. Ankara: Seçkin Yayıncılık.

Haser,Ç.\& Ubuz,B. (2002).Kesirlerde kavramsal ve işlemsel performans.Eğitim ve Bilim,27(126),5361.

Işı,C. \& Kar,T.(2012). 7. sınıf öğrencilerinin kesirlerde toplama işlemine kurdukları problemlerin analizi. Illköğretim Online, 11(4), 1021-1035.

Işık,C. \& Kar,T.(2014). ortaokul yedinci sınıf öğrencilerinin kesirlerle çıkarma işlemine kurdukları problemlerin analizi. Ilköğretim Online, 13(4), 1223-1239.

Soylu,Y. \& Soylu,C. (2005). İlköğretim beşinci sınıf öğrencilerinin kesirler konusundaki öğrenme güçlükleri: kesirlerde sıralama,toplama,çarpma ve kesirlerle ilgili problemler.Erzincan Eğitim Fakültesi Dergisi 7(2), 101-117.

Van De Walle,J.A.,S.Karp,K.,\&Bay-Williams,J.,M. (2012). Matematik Yapmanin ve Bilmenin Ne Anlama Geldiğinin İncelenmesi.In D.Soner(Ed), Illkokul ve Ortaokul Matematiği Gelişimsel Yaklaşımla Öğretim(ss. 13-31). Ankara:Nobel Akademik Yayıncılık.

Karasar, N. (2018). Bilimsel araştırma yöntemi. Ankara: Nobel.

Kocaarslan, M. (2012). Tanılayıcı dallanmış ağaç tekniği ve ilköğretim 5. sınıf fen ve teknoloji dersi maddenin değişimii ve tanınması adlı ünitede kullanımı. Mustafa Kemal Üniversitesi Sosyal Bilimler Enstitüsü Dergisi, 9(18), 269-279.

Kocaoğlu, T \& Yenilmez,K. (2010). Beşinci sınıf öğrencilerinin kesir problemlerinde yaptıkları hatalar ve kavram yanılgıları. Dicle Üniversitesi Ziya Gökalp Eğitim Fakültesi Dergisi, 14, 71-85.

Meb, (2018).Matematik dersi ögretim programı (ilkokul ve ortaokul 1,2,3,4,5,6,7 ve 8.siniflar).Ankara.

Okur,M.\& Gürel,Z.Ç. (2016). Ortaokul 6. ve 7. sınıf öğrencilerinin kesirler konusundaki kavram yanılgıları. Erzincan Üniversitesi Ĕ̆itim Fakültesi Dergisi, 18(2), 922-952.

Orhun, N. (2007). Kesir işlemlerinde formal aritmetik ve görselleştirme arasındaki bilişsel boşluk. İn̈̈n̈̈ Üniversitesi Eğitim Fakültesi, 8(14), 99-111.

Önal,H. \& Yorulmaz,A. (2017). İlkokul dördüncü sınıf öğrencilerinin kesirler konusunda yaptıkları hatalar. Eğitim ve Toplum Araştırmaları Dergisi, 4(1), 93-113.

Pesen,C.(2008).Kesirlerin sayı doğrusu üzerindeki gösteriminde öğrencilerin öğrenme güçlükleri ve kavram yanılgıları.İönü Üniversitesi Eğitim Fakültesi Dergisi,9(15),157-168.

Söğüt,G.Y. \& Yazgan,Y. (2018). 7. Sınıf öğrencilerinin kesirleri karşılaştırırken kullandıkları referans stratejileri. Kastamonu Education Journal, 26(3), 823-833.

Şiap,İ.\& Duru,A. (2004). Kesirlerde geometriksel modelleri kullanabilme becerileri. Gazi ÜniversitesiKastamonu Ĕgitim Dergisi, 12(1), 89-96. 
Toluk, Z. (2002). İlkokul öğrencilerinin bölme işlemi ve rasyonel sayıları ilişkilendirme süreçleri. Boğaziçi Üniversitesi Ĕ̈itim Dergisi, 19(2).

Uslu,C.Ş.(2006).İlköğretim 1. ve 2. kademesi ile ortaöğretim 10.slnı öğrencilerinin matematiğin temelkavramlarındaki eksik ve yanlış öğrenmelerinin karşslaş̧tırlması. Yayımlanmamış yüksek lisans tezi,Selçuk Üniversitesi Fen Bilimleri Enstitüsü, Konya. 